\title{
EXPORT ACTIVITY PATTERNS OF BORDER REGIONS IN POLAND
}

\author{
Barbara Szejgiec-Kolenda \\ Institute of Geography and Spatial Organization Polish Academy of Sciences \\ Twarda 51/55, 00-818 Warsaw: Poland \\ b.szejgiec@twarda.pan.pl
}

\begin{abstract}
The study presents a brief review of Polish border regions' participation in the global economy in 2013 based on export linkages at the local level (LAU 1). The paper offers an extended understanding of the export activity of intermediaries in foreign trade comparing to manufacturing companies. Results confirm the relatively greater importance of intermediaries activity in border areas, especially at the eastern border.
\end{abstract}

Key words: border regions, intermediaries in foreign trade, firm localisation, regional exports.

\section{Introduction}

In the face of globalization processes, international aspects of company activity are growing in importance, with an increasing number of companies being involved in international exchange as a result the issues concerning internationalization of firms as a key factor for economic growth have for years been the subject of great interest by scholars.

The first regional research works on the Polish foreign trade were comprised of analyses of foreign trade flows through transport corridors (Komornicki 2000), study of foreign exchange utilized as a basis for expanded international research study of spatial interactions taking place at the regional and local level (Komornicki 2003), and analysis taking account of differentiations in directions of linkages between particular regions and foreign markets, differences noted in internal structure of trade of particular Polish regions in relationship to specialization of suppliers and exporters operating on a given area and depending on the specificity of a region, and of comprehensive approach to the issue of interregional socio-economic linkages in combination with foreign investments projects in companies and regional competitiveness (Rogacki 2000; Maćkowiak 2008; Maćkowiak 2013). Although the phenomenon of intermediation in trade is a well-known issue, only recently it has been paid attention to in the international economic literature. Studies on activity of intermediaries in foreign trade are the theme of numerous economic papers (e.g. Bernard et al. 2007, 2011; Abel-Koch 2011; Ahn et al. 2011 and Crozet et al. 2013). Most of 
them deals with matters concerning the role of intermediary companies at the level of particular countries, and in some case with directions of export as a focal point of attention. As Schröder et al. (2003) indicates, because of the intangible nature of these firms' services, their "output" and "performance" are difficult to measure. The most serious barrier may be the lack of a conceptual framework within which to consider important research questions. A number of theoretical models, such as innovation adoption, organizational learning, and relationship marketing, have been adapted to provide conceptual underpinnings for existing export development studies. In contrast, theoretical efforts to explain export intermediaries' development as an organizational form, or to understand why some intermediaries succeed and others fail have largely been ad hoc, with little connection to the wider management, marketing, and international business literatures.

The performance of regional economies varies within the same country across a range of issues including those concerning foreign trade linkages. Borderlands, very often perceived as not only peripheral but also less developed economies, are regions of various forms of international activities, which enables to investigate the role of economic policy conditionality, borders permeability, historical traditions, distance, market size and agglomeration in the context of European enlargement (cf. Komornicki et al. 2015; Szejgiec \& Komornicki 2015; Powęska 2016; Dołzbłasz 2017; Komornicki \& Szejgiec-Kolenda 2017; Godlewska-Majkowska 2018). Moreover, Xheneti, Smallbone, and Welter (2013: 314) claims that "borderlands, as spaces of various forms of entrepreneurial activities, offer rich examples of informal entrepreneurial activities that depend on the border location to be developed and sustained."

The main aim of this paper is to present from a spatial perspective an assessment of intermediaries in foreign trade activity at border regions. The research constitutes on the one hand a study on trade companies with regard to the structure of its international connections, and on the other - a comparison with manufacturing companies activity characteristics.

\section{Data and methods}

The studies on activity of intermediaries in foreign trade clearly show (e.g. Bernard et al. 2007; Akerman 2010; Ahn et al. 2011) that adopted definitions of intermediary in foreign trade are not exactly the same. It follows from the fact that there is difficulty in gaining access to data. In the paper, an intermediary in foreign trade is a trade enterprise/company (wholesale or retail trade) dealing with transactions in foreign trade (export and/or import), located in Poland. The data include export of goods in terms of value-based data - i.e. activity carried out by intermediary companies in international trade, which are engaged exclusively or in a prevailing part in purchasing of goods with a view to sell them, acting on their own behalf, at their own account and risk, that is belonging to section G, in 2007 Polish Classification of Activities they appear under the title: "Wholesale and retail trade; repair of motor vehicles, excluding motorcycles" as well as the effects of activity of companies specialized in intermediation in purchase or sale of goods.

Data on exports in 2005 and 2013 come from information collected on the borders (EXTRASTAT) or under the framework of EU reporting (INTRASTAT) gathered by the Analytical Centre of Customs Administration.

The analysis focuses on the process of gradual integration within the world economy of local economies at border regions in Poland, understood as LAU 1 units divided into 7 sections of the borders with neighbouring countries situated within $50 \mathrm{~km}$ of the border as indicated in the National Strategy of Regional Development 2010-2020 (KSRR 2010, fig. 1). Border areas are mostly 


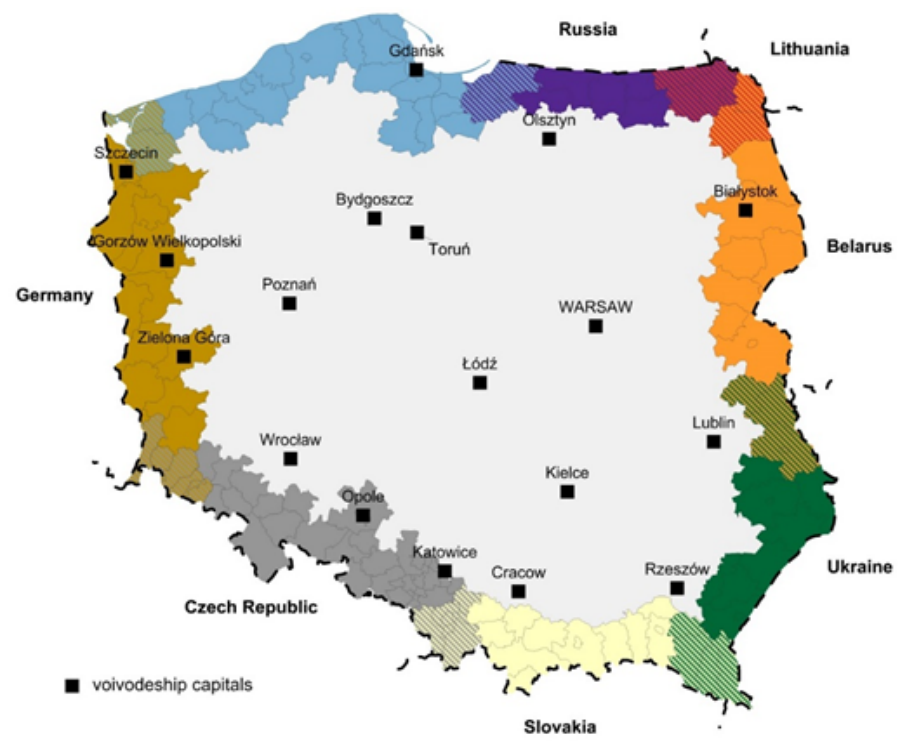

Figure 1. The area under analysis Source: author's own elaboration

rural areas without major urban centres, except for Szczecin at the border with Germany and a part of the southern border (including the Upper Silesia).

\section{Results}

\section{Export performance of border regions}

The key moment to the development of international trade in Poland was the process of economic transformation, initiated in the1990s. Polish companies conformed to the world's trends that were associated with broadening the scope of economic activity, and the most preferable form of foreign expansion was and still is product expansion. Changes that occurred after 1989 led to an increased spatial mobility and growth in trade activity, particularly in big urban centres and the west of the country as the growth poles strengthened by the FDI and in the borderlands, where development of small-scale forms of trade took place (Werwicki 1994; Domański 2001; Powęska 2002). Polarisation of the economic space of Poland still remains an important factor for spatial and temporal explanations of export performance of the regions (4532 USD per capita - Polish average, 3929 - in border areas, Table 1, Fig. 2).

The level of export activity is also emphasized by the fact that in 2013 the volume of exports per capita at the border with EU countries was three times higher than with countries outside the Schengen area (4037 against 1493 USD per capita). Nevertheless, this variation is more on the eastwest line, because the areas near the Lithuanian border have a similar level of exports to the entire eastern border (1574 USD per capita). 


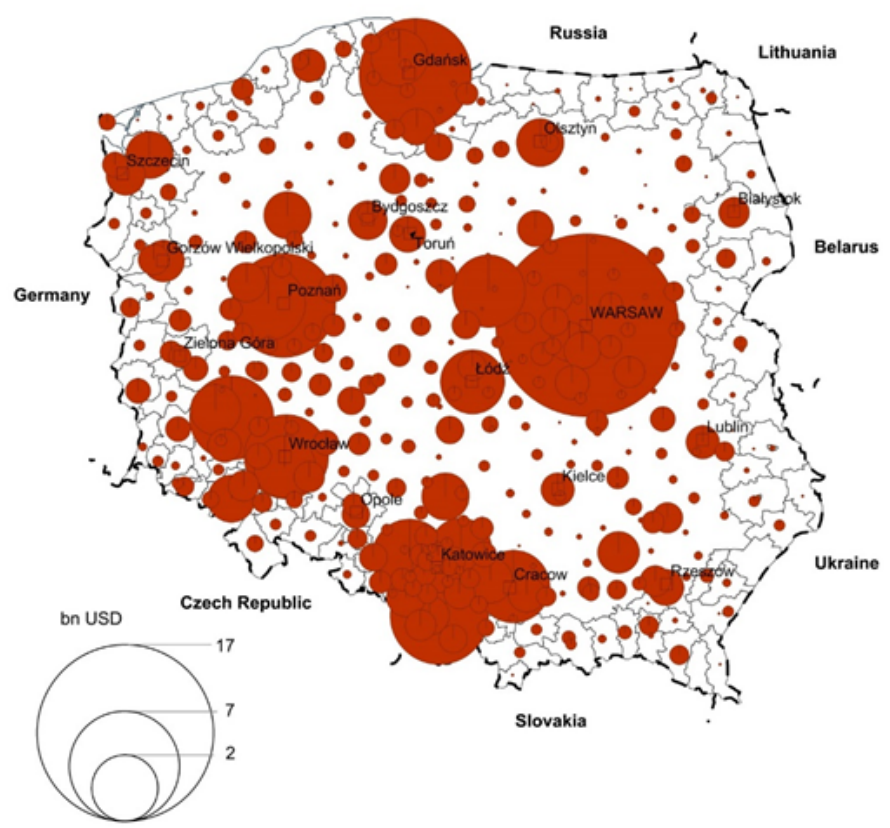

Figure 2. Total exports from Polish regions in 2013

Source: author's own elaboration

Intermediaries play an important role in international trade. Though on a national level their share in Polish export or import constitutes approximately one fifth of the total foreign turnover (16.8\% in 2013, table 1), on a local level there occur significant differences. Spatial distribution of intermediaries' share in the particular LAU 1 units is also characterized by great differentiation. It can be assumed that intermediaries' activity has a greater significance in eastern Poland, in the light of trade with Ukraine, Belarus and Russia (Fig. 3). It is also important to note the fact that intermediaries are to a large degree micro-, small- and medium-sized companies, in contrast to manufacturing enterprises exporting and importing goods. Intermediaries tend to concentrate their activities in major agglomerations in the country or in areas close to the state borders. This means that the degree of spatial concentration of their business activity is definitely greater than that of producers selling for export.

The importance of intermediaries in foreign trade is relatively higher in border areas, peripheral and less developed economically. To some extent, this is conditioned by the traditions of cross-border bazaar trade. Part of this type of activity has evolved towards entities conducting official commercial activities, specialized in transactions with neighbouring countries. Thus, the significance of border areas in economic relations with foreign countries is growing, even in conditions of a weaker production base. In the period 2005-2013, both in border areas and in the whole country, the dynamics of intermediaries export was higher than the total export (Table 1), while at the border with EU countries this difference was definitely greater.

The regularities of the spatial distribution of the volume of exports carried out by intermediaries are similar to total exports. While the share of intermediaries exports was particularly high on the eastern border sections (at some sections above $60 \%$ of the total exports was the indirect mode of export). The largest share in the export market was made by intermediaries located near 
Table 1. Characteristics of border regions performance in the global economy in Poland in 2013

\begin{tabular}{|c|c|c|c|c|c|c|c|c|c|}
\hline $\begin{array}{l}\text { Border areas } \\
\text { with: }\end{array}$ & $\begin{array}{c}\text { Total exports per } \\
\text { capita (USD) }\end{array}$ & \begin{tabular}{|c|} 
Exports to \\
industry sold \\
production \\
{$[\%]$}
\end{tabular} & $\begin{array}{c}\text { Dynamics of } \\
\text { total exports } \\
{[2005=100, \text { p.p.] }}\end{array}$ & $\begin{array}{c}\text { Share of } \\
\text { intermediaries } \\
\text { exports in total } \\
\text { exports [\%] }\end{array}$ & $\begin{array}{c}\text { Dynamics of } \\
\text { intermediaries } \\
\text { exports } \\
{[2005=100, \text { p.p.] }}\end{array}$ & $\begin{array}{c}\text { Share of } \\
\text { Germany in } \\
\text { total exports } \\
{[\%]}\end{array}$ & $\begin{array}{c}\text { Share of } \\
\text { Germany in } \\
\text { intermediaries } \\
\text { exports [\%] }\end{array}$ & $\begin{array}{c}\text { Share of } \\
\text { neighboring } \\
\text { countries in total } \\
\text { exports [\%] }\end{array}$ & $\begin{array}{c}\text { Share of } \\
\text { neighboring } \\
\text { countries in } \\
\text { intermediaries } \\
\text { exports [\%] }\end{array}$ \\
\hline Russia & 1666 & 54.9 & 231.1 & 12.5 & 265.2 & 24.1 & 14.4 & 9.3 & 69.9 \\
\hline Lithuania & 1574 & 49.7 & 205.2 & 20.9 & 378.3 & 21.2 & 21.4 & 15.1 & 72.1 \\
\hline Belarus & 1708 & 60.9 & 217.6 & 37.8 & 321.0 & 24.7 & 10.1 & 13.4 & 79.5 \\
\hline Ukraine & 993 & 49.0 & 194.0 & 23.0 & 182.1 & 28.7 & 18.1 & 17.0 & 52.0 \\
\hline Slovakia & 4540 & 55.3 & 183.5 & 6.7 & 298.3 & 18.6 & 12.7 & 7.9 & 60.6 \\
\hline Czech Republic & 5959 & 63.4 & 200.5 & 8.1 & 397.7 & 26.1 & 24.6 & 11.3 & 72.4 \\
\hline Germany & 4533 & 65.3 & 195.2 & 10.4 & 269.7 & 39.8 & 55.3 & 40.3 & 42.6 \\
\hline $\begin{array}{l}\text { Border areas - } \\
\text { total }\end{array}$ & 3929 & 61.1 & 201.4 & 11.0 & 319.2 & 28.4 & 29.6 & 17.3 & 59.8 \\
\hline $\begin{array}{l}\text { Border areas - } \\
\text { EU countries }\end{array}$ & 4037 & 64.2 & 197.1 & 10.9 & 281.3 & 39.1 & 52.7 & 37.9 & 47.2 \\
\hline $\begin{array}{l}\text { Border areas - } \\
\text { non-EU countries }\end{array}$ & 1493 & 57.0 & 216.7 & 27.0 & 270.3 & 26.1 & 12.7 & 13.0 & 72.3 \\
\hline Poland - total & 4532 & 56.4 & 207.3 & 16.8 & 249.1 & 25.9 & 21.5 & 4.1 & 94.9 \\
\hline
\end{tabular}

Source: author's own elaboration 


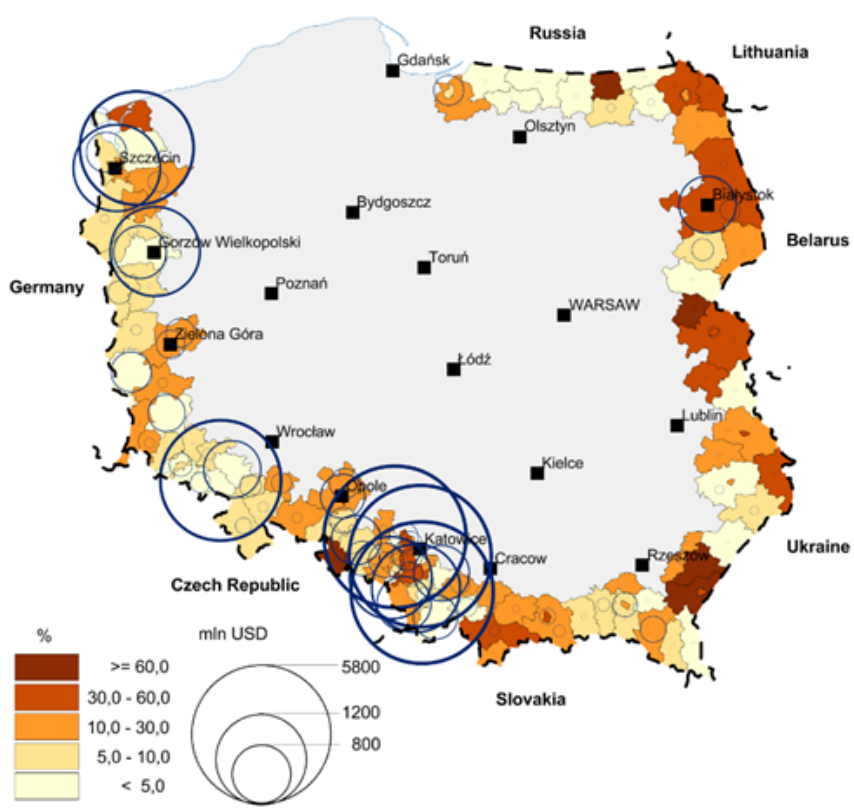

Figure 3. Intermediaries exports from Polish regions in 2013 Source: author's own elaboration

the border with Belarus (nearly 40\%) and with Ukraine and Lithuania (above 20\%, table 1 ). To some extent, it is surprising that the average share of intermediaries in total export in border areas was lower than the average in the country (11.0\% compared to $16.8 \%)$, it results in the importance of large urban centers with a larger scale of total exports, concentrating large intermediaries.

\section{Export activity reflecting border relations}

Export activity in border areas shows stronger relations with neighboring countries. Over $17 \%$ of total exports was exports to neighboring countries (only $4.1 \%$ in the country). The share of exports with neighboring countries is three times higher in the case of sections bordering EU countries. This was mainly due to the high share of exports with Germany on this border section (over $40 \%$ ), but it is a general tendency that the share of exports with Germany decreases with distance from the border (gravitational model of exports, see: Komornicki 2003; Komornicki et al. 2015).

Nearly $60 \%$ of the intermediaries exports in border areas corresponded to neighboring countries, it confirms the specialization of export with these countries. Intermediaries in foreign trade located at the eastern border are characterized by high specialization in the field of export import directions resulting from the use of know-how developed while conducting less formal cooperation in the framework of cross-border trade.Only in areas bordering Germany this share was below $50 \%$, which means that these areas have a tendency to approach export patterns specific to the country in general. The export activity of intermediaries, unlike in the case of both direct and indirect exports, is characterized by a half higher share of exports with neighboring countries at a section with non-EU countries. 


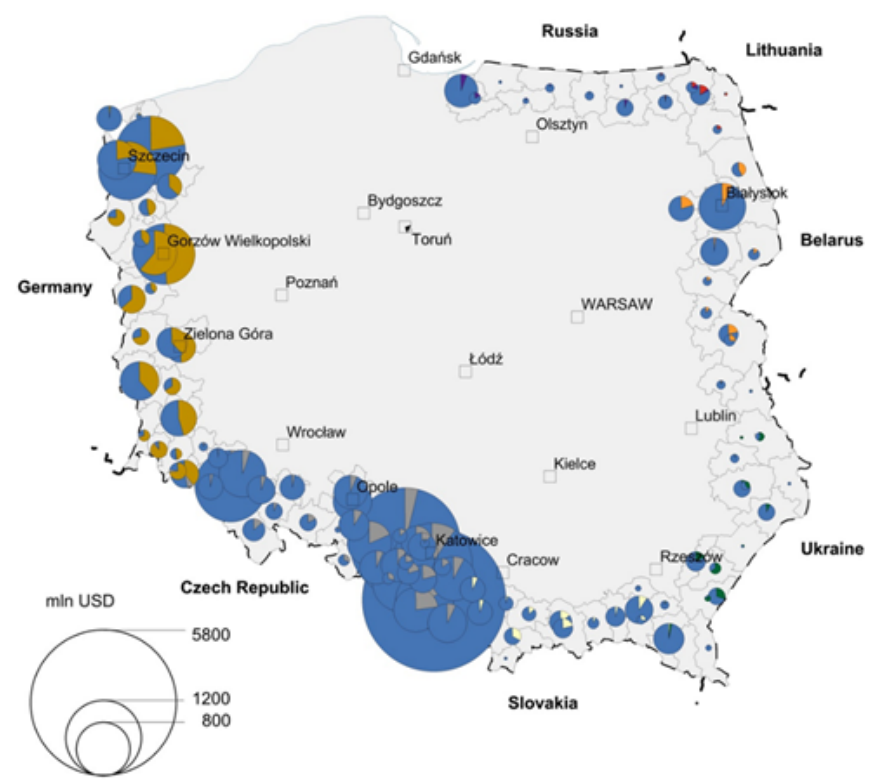

Figure 4. Share of exports to neighbouring countries in 2013 - all exporters Source: author's own elaboration

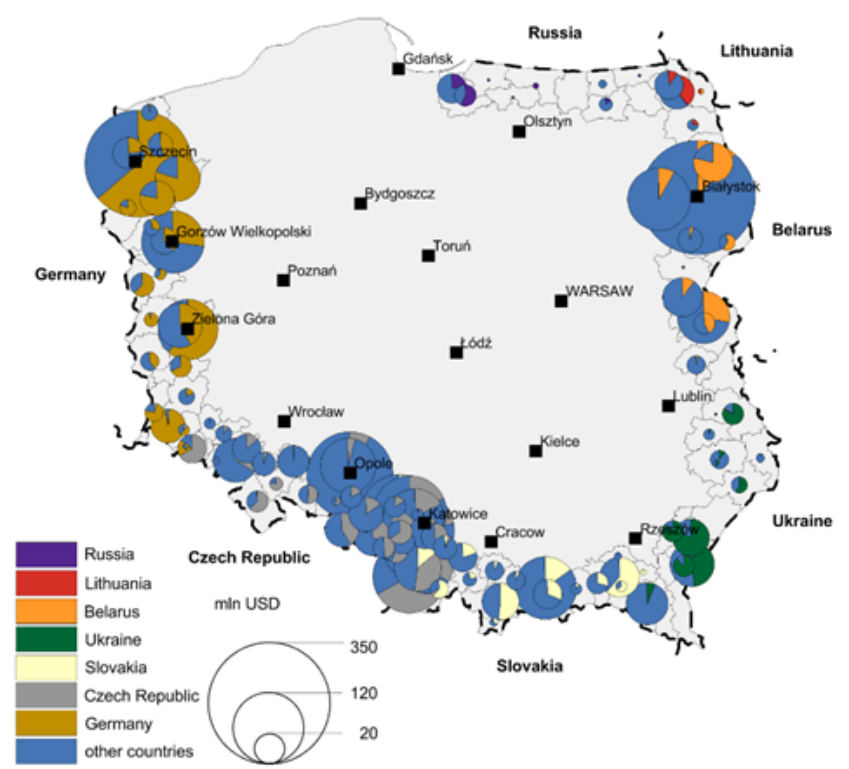

Figure 5. Share of exports to neighbouring countries in 2013 - intermediaries Source: author's own elaboration 


\section{Intermediaries in border regions}

Analysing the structure of the population of intermediaries in foreign trade, it may be assess to some extent the durability and vitality of export activity. Assuming that a certain stability of relations is evidenced by the length of functioning of intermediaries on the market, areas bordering Russia and Lithuania have a large percentage of intermediaries, over $30 \%$ of entities, started operations before 1997. However, a relatively high percentage of enterprises established in the 3 years preceding the study was marked by areas bordering Lithuania (also), Belarus and Ukraine (above $20 \%)$. In these areas, the time from establishing a business to foreign expansion is shortened. It can also be pointed out that some restrictions on the establishment of intermediaries in the period 2002-2005 were observed at the border with Russia, which points to weakening of the attractiveness of relations.

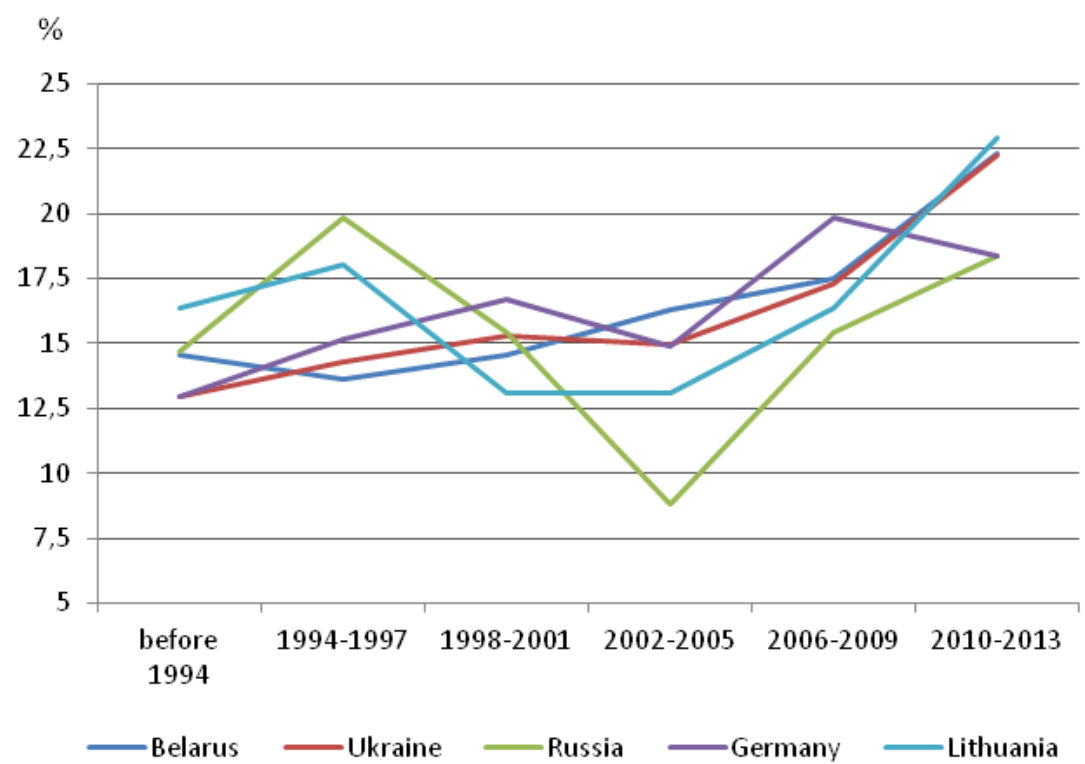

Figure 6. Intermediaries by time of set-up and selected border areas in 2013 Source: author's own elaboration

\section{Summary}

Over the past decades there has been noticed evolution in the process of internationalisation of border-located local economies in Poland. Main conclusions resulting from these changes are following:

- - border regions increasing interest in entering foreign markets, but the overall participation in the global economy still may be considered under the core-periphery framework;

- - western border is characterised by increased flows of goods to Germany; i.e. consequently to the tendency to cooperate with the largest, stable and geographically close market;

- intermediaries as companies with lower entry costs play an important role in the process of 
economy internationalisation, particularly in less-developed or peripheral regions; also in case of Poland - this partly results from traditions of 'suitcase trade' across the border;

- location and activity of intermediaries is strongly conditioned by available network of transport corridors, at the Eastern border - also by network of border crossings and border infrastructure;

- share of 'born global' intermediaries is significantly higher than few years ago; characteristic phenomenon is also establishing enterprise for a short period 'ephemerides';

- Polish border regions are distinguished by the more pronounced intensity of the intermediaries' activity in foreign trade, with specialisation in trade with neighbouring countries; while companies located in developed regions generally opens to the non-traditional, often challenging markets.

Summing up, the obtained results confirm that in border areas, where the production base is relatively weaker than in the rest of the country (in particular taking into account the eastern border of the country), intermediaries in foreign trade play an important role in establishing economic relations with foreign countries. Intermediaries are selected by the firms from the SME sector for which indirect forms of foreign expansion are more profitable (Benard et al. 2007, 2011; Ahn et al. 2011). At the same time, these areas show stronger relationships with neighboring countries, which is confirmed by the results of studies of other authors regarding both the economy and institutional, cultural or social relations (Komornicki et al. 2015; Szejgiec \& Komornicki 2015; Powęska 2016; Dołzbłasz 2017; Wróblewski 2018) and already established relationships lead to further intensification of these connections.

\section{Acknowledgements}

The study is a result of a research project: 'Regional diversity of intermediaries' activity in foreign trade - competitiveness and role in local economy' financed from the funds of the National Science Centre - Poland on the basis of the decision no. DEC-2014/13/N/HS4/03413.

\section{References}

Abel-Koch J., 2011. Who uses intermediaries in international trade? Evidence from firm-level survey data. Research Paper 2011/25.

Ahn J., Khandelwal A. K., Wei S., 2011. The role of intermediaries in facilitating trade. Journal of International Economics, vol. 84, pp. 73-85.

Akerman A., 2010. A Theory on the Role of Wholesalers in International Trade based on Economies of Scope. Research Papers in Economics, vol. 1, Stockholm University, Department of Economics.

Bernard A., Jensen B., Redding S., Schott P., 2007. Firms in international trade. The Journal of Economic Perspectives, vol. 21, no. 3, pp. 105-130.

Bernard A., Grazzi M., Tomasi C., 2011. Intermediaries in international trade: Direct versus indirect modes of export. National Bureau of Economic Research, Working Paper 17111.

Crozet M., Lalanne G., Poncet S., 2013. Wholesalers in international trade. European Economic Review, vol. 58, pp. 1-17.

Dołzbłasz S., 2017. Sieci współpracy transgranicznej na pograniczach Polski. Rozprawy Naukowe Instytutu Geografii i Rozwoju Regionalnego Uniwersytetu Wrocławskiego: Wrocław.

Domański B., 2001. Kapitał zagraniczny w przemyśle Polski. Prawidłowości rozmieszczenia, uwarunkowania i skutki. Uniwersytet Jagielloński, Instytut Geografii i Gospodarki Przestrzennej, Kraków.

Godlewska-Majkowska H., 2018. Polarity of the Regional Space - the Dilemma of Shaping the Investment Attractiveness of Poland. Studies of the Industrial Geography Commission of the Polish Geographical 
Society, vol. 32, no. 4, pp. 110-122.

Komornicki T., 2000. Potoki towarowe polskiego handlu zagranicznego a międzynarodowe powiqzania transportowe. Prace Geograficzne - Polska Akademia Nauk, Continuo: Wrocław.

Komornicki T., 2003. Przestrzenne zróżnicowanie międzynarodowych powiq̨zań społeczno-gospodarczych w Polsce. IGiPZ PAN: Warszawa.

Komornicki T., Szejgiec-Kolenda B., 2017. Przekształcenia przestrzennego rozmieszczenia obszarów koncentracji eksportu w Polsce. Przegląd Geograficzny, vol. 89, no. 2, pp. 269-289.

Komornicki T., Zaucha J., Szejgiec B., Wiśniewski R., 2015. Powiqzzania eksportowe gospodarki lokalnej w warunkach zmiennej koniunktury - analiza przestrzenna. Prace Geograficzne, IGiPZ PAN, 250, Warszawa.

KSRR, 2010. Krajowa Strategia Rozwoju Regionalnego 2010-2020. Regiony, miasta, obszary wiejskie.

Maćkowiak H., 2008. Struktura towarowa wymiany handlowej polskich regionów z Uniq Europejskq. [in:] D. Ilnicki, K. Janc (ed.), Przekształcenia regionalnych struktur funkcjonalno-przestrzennych. Europa bez granic - nowe wyzwania. Rozprawy Naukowe Instytutu Geografii i Rozwoju Regionalnego Uniwersytetu Wrocławskiego 3. Wrocław: Instytut Geografii i Rozwoju Regionalnego Uniwersytetu Wrocławskiego, pp. 143-154.

Maćkowiak H., 2013. Zróżnicowanie struktury handlu zagranicznego Polski w ujęciu regionalnym oraz konkurencyjność eksportowa regionów. Bogucki Wydawnictwo Naukowe: Poznań.

Powęska H., 2002. Przestrzenny wymiar handlu transgranicznego w Polsce w ostatniej dekadzie XX wieku. Geopolitical Studies, vol. 9, Warszawa.

Powęska H., 2016. Handel przygraniczny w warunkach zmian przenikalności granicy. Wydawnictwo SGGW: Warszawa.

Rogacki H., 2001. Zróżnicowanie aktywności eksportowej i importowej województw Polski. [in:] Z. Zioło (ed.). Problemy przemian struktur przemysłowych w procesie wdrażania reguł gospodarki rynkowej, Prace Komisji Geografii Przemysłu PTG, nr 3, Warszawa-Kraków-Rzeszów, pp. 43-50.

Schröder P., Trabold H., Trübswetter P., 2003. Intermediation in Foreign Trade: When do Exporters Rely on Intermediaries? Discussion Papers 226, Berlin.

Szejgiec B., Komornicki T., 2015. Spatial differentiation of Polish export linkages. Geographia Polonica, vol. 88, no. 1, pp. 173-178. https://doi.org/10.7163/GPol.0011

Werwicki A., 1994. Transformacja sieci handlu i usług na obszarach przygranicznych Polski. [in:] P. Eberhardt i K. Miros (ed.). Węzłowe problemy współpracy przygranicznej, Podstawy rozwoju zachodnich i wschodnich obszarów przygranicznych Polski, Biuletyn nr 5, Warszawa, pp. 151-161.

Wróblewski Ł., 2018. Powiqzania społeczno-gospodarcze na pograniczu polsko-niemieckim w warunkach rynku wewnętrznego Unii Europejskiej. Studia Regionalne i Lokalne, vol. 4(74), pp. 75-88.

Xheneti M., Smallbone D., Welter F., 2013. EU enlargement effects on cross-border informal entrepreneurial activities. European Urban and Regional Studies, vol. 20, no. 3, pp. 314-328. https://doi. org/10.1177/0969776411434849 